\title{
THE ADVENT OF MODERN ECONOMICS IN PORTUGAL
}

\author{
Carlos Bastien
}

\section{GHES}

Gabinete de História Económica e Social

Lisboa

1996 


\begin{abstract}
As far as economic theory is concerned Portugal has never had a strong tradition or originality. As a semi-peripherial society it has been a late receiver of innovations come out from the main producer centres of economic ideas, often in a partial, ill digested way, adapting them to the local conditions.

The post World War II years would be a crutial period in that process of import and adaptation. Then, the ruling classes became particularly aware of Portugal's economic backwardness and a strategy to achieve economic growth and modernization was implemented, while an inevitable larger integration in the world economy and cultural life took place.

Such an enviroment demanded a larger concern with economic issues and theories, weaken the position of corporative economics, which had been dominant since the 1930's, and allowed a sudden introduction of modern economic theories, namely neoclassical, keynesian, and marxist economics, by then almost unknown.

A significant reform of economic teaching, the advent of research institutions and reviews on the subject were decisive to spread the new theories.
\end{abstract}




\section{Contents}

1. Introduction

2. Economic ideas in Portugal by 1945

3 . The outset of a new epoch

4. Theoretical innovations

4.1. Corporative economics

4.2. Neoclassical economics

4.3. Keynesian economics

4.4. Marxist economics

4.5. Cooperativism, schumpeterianism and structuralism

5. The spread of educational and research apparatuses

5.1. Scientific research apparatuses

5.2. The teaching of economic ideas

5.3. The making of the economist profession

6. Concluding remarks

References

Appendix 


\section{Introduction 1}

This paper aims at analysing the conditions and the process of modernization of economic ideas in Portugal after 1945.

Firstly, we will describe the circunstances at the threshold of this period. To sum up, there wasa clear backwardness and unfamiliarity with the economic theory produced in the main innovating centres in the world.

Secondly, we will focus on the period 1945-1955, when the advent of an economic modernization strategy demanded a deep renewal in the field of economic doctrines and theories. This process would be associated with a reform of economic teaching and the advent of both research institutions and specialized reviews.

Thirdly, we will also consider the following decades, when the process of modernization of economic ideas was pushed further under the new incentivating environment, namely the larger integration of Portugal in the world economy and international cultural life. However, it has been a very slow implementation. Only very recently has a true community of economists been set up.

\section{Economic ideas in Portugal by 1945}

Prior to 1945, Portugal was a small, backward and semiperipherial national economy under an authoritarian state set up by a coup d'Etat in 1926, which led to a corporative state that was institutionalized in 1933.

The dominant strategy thought out by the new government was to mantain economic and social equilibria. The dominant social role was performed by an alliance of wealthy landowners, non-entrepreneurial industrialists, and commercial bankers.They refused both modernization and social and cultural change. Some ideologues, mainly engineers, thought out a strategy of economic growth but they were not supported either by society or by political leadership.

The economic policy implemented in the 1930's was clearly conditional upon the above mentioned goal of social and political stability. Budget equilibrium, monetary stability, autarky, but mainly the setting up of the so called 'industrial conditioning' were to become important components in a complex corporative apparatus aiming at controlling the whole of economic and social life. Such a policy was basically a voluntarist attitude relying in no refined economic theory.

1 Paper to be presented at the conference The Post-1945 Development of Economics in Europe. 
Throughout the 1930's, in spite of some efforts to create a corporative economic doctrine, economic discourse continued to be poor, non-specialized, non-theoretical. Politicians, jurists, engineers and journalists, mostly self-taught and with no specific competence, were its main interpreters.

At that time there was no social group that could be taken for professional economists; research units on the field were almost absent, scientific reviews or any other periodical publications on economic issues were rare.

The Instituto Superior de Ciências Económicas e Financeiras - I.S.C.E.F. [Higher Institute of Economic and Financial Sciences], of Lisbon, founded in 1911, was the only school at university level dedicated to economic sciences, though high level studies of political economy were in traditional law schools.

The knowledge and debates on economic theory were rather poor. Theoretical innovations that had arisen since the end of the 19th century were almost unknown. This is the case with the so called marginalist revolution. Actually, if names such as K. Menger, A. Marshall or V. Pareto were incidentally quoted, most of their works remained unnoticed. Generations of economists that would adopt critical or divergent views of the so called first neoclassical synthesis, namely institutionalists, marxists and schumpeterians, were also mostly ignored.

The teaching of economic theory in the above mentioned I.S.C.E.F., under the responsibility of professors with juridical training, was dominated by what could be consider to be a naif institutionalism. It had neither the sociological emphasis nor the critical views inherent in Veblenian institutionalism. It was a mere description of the institutional and legal aspects of economic life, as the main textbooks of this period show [MARQUES: 1934; NETTO 1936; GUEDES: 1944/6]. Economic theory was then considered to be a subject of cultural interest but of little or no instrumental value [PEREIRA: 1935].

During this period José J. Teixeira Ribeiro, a professor of political economy at the University of Coimbra from 1934/35, was the main exception to this generalization. As his Ph. D. dissertation shows, he was aware of the theories of monopoly and even of monopolistic competition [RIBEIRO: 1934]. He dared to implement an ecletic teaching - in spite of the limits imposed by the ruling culturally obscurantist regime - where both the prevailing and the less influential schools of economic thought deserved to be mentioned. Costa Leite was another exception. His study of the theory of economic crisis he was aware of the most important contributions of Cambridge's economists [LEITE: 1933].

After 1933/34, the corporative doctrine was definitely the most influential one. Its primacy led to attempts to creating something like an indigenous Portuguese corporative economic theory that would legitimate that doctrine as well as guiding the state economic interventionism. In fact it turned out to be a rough version of the Italian corporative economic theory. 
The outcome of all this was rather perverse. The expected original, consistent theory did not emerge, and meanwhile the various theoretical conceptions produced abroad were either undervaluated or introduced with great delay.

\section{The outset of a new epoch}

By 1945, almost all over the world, a new economic, social and cultural epoch arose. Portugal was not an exception. The immediate post World War period turned out to be pivotal in Portuguese society.

In spite of the persistence of clear signs of backwardness, a process of industrialization and economic modernization took off in the beginning of the 1950's. Social structures were reshaped as the industrial burgeoisie strengthened its position within the rulling social coalition.

In spite of its apparent stability, the political regime also underwent some changes. The appearance of stronger anti-fascist movements, both of liberal or marxist inspiration; the emergence of lobbies inside the regime apparatus; and popular protest were responsible. After a short period of international isolation, internal political disturbance, and some incertainty as far as its survival is concerned, the so called Estado Novo [New State] could keep and even develop its corporative apparatus after all.

However, the new international environment, the partial revival of the social background of the regime, political pressure, and the new economic ideas, all had important consequences. The purely conservative strategy of the social equilibria implemented since the 1930's was significantly complemented with a strategy of industrialization supported by new forms of economic regulation, under protectionist policies. By the beginning of the 1960's a new strategy of internationalization was taking place. It was interrupted in 1974/75 when a revolution overthrew the Estado Novo and tried to implement a socialist society. After that short period the previous strategy of internationalization reemerged, being heavily confirmed when Portugal became a full EEC member in 1986.

The cultural scene, as well, experienced some changes at the end of World War II in spite of the persistence of traditionalist doctrine and of the restrictions generated by the obscurantist cultural policy of the Estado Novo. These changes took place mainly outside official circles. The import of new scientific knowledge, and the strengthening of some of the already existent artistic, philosophical and scientific ideas, contributed to a renewed rationalism, an increasing value attached to the idea of progress, and an underlining of the civilizing and instrumental role of science. 
Those changes were also experienced in the specific field of economic ideas. Popular and cultivated opinion, as well as democratic oposition forces and even a developmentalist group inside the ruling coalition, demonstrated a major concern towards economic issues and were aware of Portuguese backwardness.

Common sense began to reject the idea that Portugal was inevitably a poor country because of the scarcity of its natural resources. In the following years, as the relationship with the other European societies was intensified, claims for better standards of living, closer to the levels of other western economies, emerged.

Several economists, namely those who were commited to support political opposition movements, made severe attacks on the uneven distribution of income and on the conservative nature of the effective economic strategy, and they put forward pro-development views which demanded the transformation of the basic economic and political structures of the country. This process would include the dismantling of the corporative economic apparatus, the nationalization of big industry and banks, the implementation of an agrarian reform, and also a change of political structures towards democracy.

Even men committed to the regime felt that, in a period of political uncertainty, this was a unique opportunity, and they tried to force their pro-growth views. Ferreira Dias and Araújo Correia, both engineers, were the most representative among others. They were commited to the regime but they were not actually a group. Nevertheless they shared some common views, namely, a cautious mistrust of the efficiency of the corporative apparatus but also a belief in an authoritarian, strong, interventionist state. Actually, they thought that to achieve a successful catching-up process the state should reorganize and concentrate most of industrial branches by administrative means [DIAS: 1945]. It should also be directly responsable for the infrastructures needed to make the best economic use of the rivers, in order to modernize the agricultural sector, and, even more important, to obtain a source of energy to foster industrialization. In their opinion, long run planning should be an important regulating mechanism of this process [CORREIA: 1952].

Their immediate success was limited, but their projects proved to be quite relevant to the economic modernization actually experienced by Portugal in the following decades. Even the quite conservative corporative oficial doctrine would show a clear sensitivity to the ideas of industrialization, economic planning and economic growth. In the beginning of the 1970's technocratic views would take over this trend [MARTINS: 1970]. 


\section{Theoretical innovations 1}

The subfield of economic theories was also experiencing important changes as a reaction to the emergence of paradigms other than corporative economics.

\subsection{Corporative economics}

Despite the survival of the Estado Novo to the postwar critical enviroment its corporative economic apparatus was not significantly strengthened. Corporations would continue to be substituted during the next decade by a dense network of public agencies responsible for an extended degree of economic regulation. Actually they would be more efficient in control than in coordination.

The apparent failure to set up an effective corporative economy, and the new international post World War II environment, proved to have far-reaching consequences. The defeat of the fascist states and the consequent contempt for the corporative ideal led to the discredit of its doctrine and to a temporary collapse of the effort to introduce corporativist theoretical innovations. However, as the Estado Novo managed to survive, a new period, the so called "new corporative take off" [CARDOSO: 1949: 8-9], emerged.

Some economists tried then to reimpose the corporative doctrine and theory, and this provided a touch of Portuguese originality into the international intellectual economic scene.

The theorizing adopted in the first half of the 1950's aimed at integrating some new topics and concepts, many of which were imported from other theoretical, doctrinal schools.

The initial theoretical topics to concentrate the efforts of the corporative economists of the first period, namely the definition of homo corporativus, the determination of the corporative price, and of the corporative wage, were extended to three new items: efficiency and equilibrium of the corporative firm, economic planning, and the theory of economic systems.

The first of the these items led to the most curious results. The attempt was to determine, in a Marshallian style, the equilibrium conditions of the firm in a corporative system by comparing the hypothetical equilibrium of the same firm in a capitalist system context. The main conclusion of this counter-factual exercise was that, under a corporative system both a higher level of employment and a stronger growth dynamics would be achieved [NUNES: 1952; SILVA: 1953].

1 For detailed bibliographical references covering the period 1945-1954 see BASTIEN: 1989 where systematic analysis on this subject was provided. 
As a theoretical topic, economic planning was ignored by corporative economists before 1950. The advent of this instrument of economic regulation in several Western European mixed economies after World War II generated some interest in the subject. In the long run, discussions on the theme would lead to the introduction of modern techniques of economic planning. However, in the short run, the point was to justify the compatibility of an economic plan (by then considered a typical instrument of the socialist economies, and so to be despised) with its use as an instrument in the context of the corporative structure.

It was accepted that "we are not supposed to expect that common welfare will come automatically", and that "the corporative economy will only realise its aim fully - common welfare through a planned intervention implemented by the corporations in cooperation with the State" [PEREIRA: 1953: 50]. This would imply the institutionalization of a complex hierarchical structure of corporative councils.

In this period, as far as the theory of economic systems is concerned, the crucial change was the abandonment of the idea that the corporative system should be a third way between capitalism and socialism. Consequently the efforts to build up a corporative economics fade out. The adoption of the theory of economic systems that W. Eucken, set out in 1939, implied that from that time corporative economies would be considered, from then on, simply as a particular mix of market and centrally planned economies - as in any other existing economies - and so falling under general economic laws [MOURA: 1950].

Stubbornly, however, some jurists went on insisting in that "the main features of a corporative economy separate it from any other system" [MARTINEZ: 1960: 35]. Even in the 1970's, when the Estado Novo was enduring its final crisis, there were still attempts to reassert the corporative ideal and to prove that the corporative system could lead to economic modernization [PIRES: 1973; XAVIER: 1973].

\subsection{Neoclassical economics}

Along with the abandonment of the above mentioned project to create a corporative economics, at the end of the 1940's, there was an opportunity to import the almost unknown neoclassical economics.

This school of economic thought would prove to be an important device to legitimate the institutionalization of the liberal capitalist order after the eventual collapse of the Estado Novo in the aftermath of World War II. In case of its historical survival, that new theoretical body could still be useful to legitimate several important political and economic ideas of the Estado Novo. This was the 
case with such topics as economic agents' harmony, monetary stability, balanced budget, economic inequality, etc.

In these circunstances, and considering that academic institutions were heavily dependent on the political leadership, there was a fundamental condition for a successful introduction of the new paradigm: it had to be 'purified' from the liberal political prescriptions with which it had usually been associated.

The fist step towards the acceptance of this new school was to demonstrate its scientific nature. It was important to isolate it from important trends in the economic literature of the epoch, both in terms of methodology and concepts. However, any doctrinal discussion of the economic systems or on guidelines of economic policy was completely unacceptable to the majority of the academic staff. It was only acceptable as positive economics, "looking only for facts and its laws (...) prescribing nothing, neither normative, nor imperative" [BARBOSA: 1943: 236] to avoid any pollution either with doctrine values or with political demands.

The diffusion of the neoclassical paradigm was transmitted through university textbooks deviating little from the international standard. Some particularities were the result of specific conditions, namely a late introduction of the theory in Portugal.

As far as consumer theory is concerned, some textbooks published in the 1940's failed to make clear the distinction between the first versions of the marginalist analysis, based on cardinal utility, and the more refined versions based on the indifference curves and ordinal utility formulated by Pareto and later by Hicks. In any case it is apparent the concern in underlying the merely formal nature of that type of analysis, namely when noting that "indifference curves are quite vague, imprecise concepts that can be accepted in a logical level but [they] are absolutely useless for practical purposes ." [BARBOSA: 1950(1): 122]

Production theory was also difused according to the conventional, international presentation. It is worth emphazising that this part of the theory had the most significant immediate impact in studies of applied economics, namely in the appraisal of the efficiency of some industrial sectors.

Market theory fitted this pattern. Textbooks in the 1940's included detailed references to perfect competition, to unilateral and bilateral monopoly and oligopoly markets. Their originality, if any, lay in underlying that perfect competition markets had a mere didactic value, but certainly not prescriptive value [BARBOSA: 1950(2): 461], and in introducing the distinction between what were called "theoretical prices" and "real prices" in order to justify state intervention on prices [BARBOSA: 1950(2): 544].

On the whole, these topics were discussed in a rather dogmatic way. The marginalist analysis was said to be superior because it was "appealing to gather all the elements inherent to value, while previous theories were aware of the fact that it depended on utilility, scarcity or labour but could not combine these factors" [ULRICH: 1948: 40]. The realism of such a construction was 
never discussed, neither how to measure utility nor the validity of the law of diminishing returns, just to mention two of the weakest aspects of the theory.

During the next decades, neoclassical economics would remain basically an academic subject, having hardly any impact on economic policy. The law of increasing returns was incidentally quoted to support the industrial policy which favoured concentration. The virtues of competition where also incidentally recalled namely whenever some industrialist felt he was being hurt by the aplication of the 'industrial conditioning' legislation.

During the last two decades neoclassical economics has gained credibility in the context of the so called second crisis of economic theory and the advent of the liberal wave of the 1980's. Only then were some practical implications of the theory felt, and general economic equilibrium theory received significant scholarly attention.

\subsection{Keynesian economics}

Any appraisal of the meaning of the "keynesian revolution" in Portugal during the 1940's must take account of how small and backward Portugal was. It had not yet experienced a take-off, and so its monetary and financial markets were very small and inefficient. Economic cycles were basicaly determined by the impact of external forces and by agricultural cycles. Unemployment was still hidden by the important role of the traditional agriculture structures.

The impact of keynesianism was also minimized by political, and cultural factors. The theoretical discussion and analytical progress that took place in Cambridge during the "high theory years", which led to General Theory, were unknown to the large majority of Portuguese economists. Though he never read Keynes, Salazar, the top leader of the Estado Novo, who had been professor of political economy and public finance at the University of Coimbra, thought keynesianism was "a disease" [NUNES: 1986: 59]. This fact is not insignificant, though it may be considered rather strange, once one realises the above mentioned rigid dependence of the university on the political leadership. Above all, the strong economic state intervention of the Estado Novo had, long before, been well established and had its own forms of legitimation (e.g. corporativist doctrine). So, Keynesian ideas were not very appealing especially as they minimized the importance of, and even contradicted, the rigid monetary and budgetary orthodoxy, which was a leit-motiv of the Estado Novo propaganda.

It was no suprise that those mainly responsible for the introduction and diffusion of Keynesian ideas were economists in political oposition to the regime - some of them were expelled from the university. They thought the new paradigm could be used to legitimate their oposition to Salazar's 
economic and cultural policy. General Theory abstracts were published [ABREU: 1948; PINTO: 1952], Keynes's innovations in economic analysis were underlined; and the similarities and differences between Marx's and Keynes's ideas were discussed [SOUSA: 1950]. Some of those papers dared to demonstrate the irrationality of some aspects of Portuguese economic policy from a keynesian point of view [ABREU: 1949; LEAL and FALCÃO: 1952].

Some time later, keynesianism would be accepted by the Estado Novo economists, at least in its pure, formal character. As it was no long feasible to ignore the theoretical innovations, they disseminated an interpretation of the paradigm that would legitimate the corporative system and the economic policy implemented under it. They mentioned that "the possibility of a third system (...) had been already theoretically accepted by distinguished economists, namely J. M. Keynes", and that "that system can not be other than the corporative system" [VEIGA: 1944: 214-215]. As far as economic policy is concerned, they wrote, for instance, that "some keynesian doctrines, which were not ignored, were consistent with some attitudes reflected in the Portuguese laws and administration" [OLIVEIRA: 1947: 147].

In the 1950's, the keynesian revolution was introduced into the universities. From then on, keynesian economics became dominant at that level, and at last influenced the political discourse. Textbooks introduced the main concepts of the new theory included in the so called neoclassicalkeynesian synthesis based on the IS-LM model. In the mid 1950's Ph. D. dissertations show a clear influence of keynesian theory [BELEZA: 1955; NUNES: 1956; PINTO: 1956].

In the 1960's the most important textbooks used in the teaching of economic theory reveal a powerful influence of Keynesian ideas [MOURA: 1964 and 1969a]. Important interpretations of the Portuguese process of economic growth were also influenced by that paradigm [MOURA: 1969b]. The most prominent men of the Estado Novo, both in the political and economic scene, became sensitive to the new economic conceptions. Araújo Correia, mentioned above, tried to support his developmentalist ideas using Keynesian concepts. The Second Development Plan, elaborated in 1958, was based on a Harrod-Domar type mathematical economic growth model. After 1955, even the Minister of Finance's discourse integrated concepts and a keynesian lexicon, though the classical financial orthodoxy inherent to Salazar's governments persisted.

Portugal was also touched by the second crisis of economic theory, and by some divergent and critical views that emerged in that context. However, the neoclassical-keynesian synthesis remained the main school of economic theory taught in the universities.

With respect to economic policy, matters were different. After a brief period of dominance of socialist economics in the mid 1970's, monetarist economics became the mainstream in the 1980's and in the first half of the 1990's. 


\subsection{Marxist economics ${ }^{1}$}

Marxism was another school of economic thought in Portugal during this period. It was not entirely new to the Portuguese culture for its presence was apparent during the 19th century. However, it was not until the 1930's that a first generation of marxist intellectuals appeared. Their action and impact would only be felt in economics, in the post war period.

The spread of marxist ideas was the consequence of its prestige as an ideal, of the strenghtening of workers movement and of communist forces during war time. By then, some Marxist economists emerged, most of them non-academic. They introduced and discussed several topics relating to Portugal, such as imperialism, workers immiseration, underdevelopment and agrarian reform.

This doctrinal intervention, some times propagandistic, was accopanied by several theoretical developments. Among these, the subjective theory of value, predominant in the academy, was criticized and its limitations were underlined, while the superiority of the Marxist theory of labourvalue was emphasized [CASTRO: 1948]. An underconsumptionist interpretation of Portuguese capitalism [CASTRO: 1949] was a lasting interpretative matrix among Portuguese marxists and the broad trends of the agricultural sector were described [CASTRO: 1945]. Attempts were made to test the validity of the theoretical law of pauperization under Portuguese economic conditions [ALARCÃO: 1948]. However, as mentioned earlier, the most important and lasting theoretical efforts of these economists were dedicated to the criticism of Keynesianism.

During the1950's, in Portugal as elsewhere, Marxism retreated, both in respect of its political and practical attitude, and its theoretical elaboration and diffusion. However, after the mid 1960's it once again became appealing to the Portuguese intellectuals, following a similar trend in Western Europe.This was to have positive effects on economic thought.

Abstract theoretical topics, such as the historical forms of capitalist mode of production, and the theory of economic crisis, attracted the attention of these authors, and there were some written elaborations. However, many other economic topics, that were central in the international Marxist discussions, were generally ignored in Portugal. Controversial themes, such as the evolution of the world economy, the division of labour inside the factory, the functioning of the socialist economies, were mostly absent.

Meanwhile, after the mid 1960's, relatively numerous writtings appeared dealing with particular aspects of Portuguese capitalism. The most important theoretical reference was the theory of State Monopoly Capitalism according to the interpretation of the French Communist Party and of the Academy of Science of the USSR. However, the urgency of political intervention, gave to

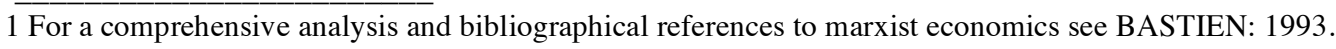


most of these texts a short-term approach and a critical descriptive character. Álvaro Cunhal's book on the agrarian question [CUNHAL: 1966] but mainly his report on the Portuguese situation [CUNHAL: 1964], are important exceptions. He tried to analyse Portuguese capitalism by means of a broad, systematic approach.

The April 25, 1974, military coup toppled the forty-eight year old fascist dictatorship. It changed many features of the political, economic and cultural realities, and - and this is now the main point for us - it opened up the doors to a larger spread and influence of Marxism. Since then Marxist ideals have echoed powerfully in the academy, namely because Marxist intellectuals, previously forbidden to speak out, were now integrated as scholars and investigators in some universities.

Armando Castro, who had just been authorized to lecture at the university, published the first academic textbook on Marxist political economy ever written in Portugal [CASTRO: 1983]. At the same time, the presentation of several Ph. D. dissertations on subjects such as inflation, economic crises, economic policy, or history of economic thought, just to mention a few, were a significant proof of the impact of this paradigm of economic thought in the academy.

\subsection{Cooperativism, schumpeterianism and structuralism}

Portuguese intellectuals were aware of other schools of economic thought, but their influence was minor.

One was the so called social economics, especially its cooperativist approach. It had had some tradition in Portugal since the 19th century, as in some other catholic countries, and reemerged as a project to reorganize both the economy and the society in the aftermath of World War II and again in the 1970's, when the collapse of the Estado Novo made the reformulation of the Portuguese economic structures an acute issue.

According to its supporters "the feasible socialism to be implemented now, [is not yet] pure socialism but a pre-socialism" [SÉRGIO: 1947: 17-18]. It would rely temporarily on a large public sector, which would be a temporary device to assure the way to a generalized cooperative system.

The defence of this system was basically ethical - " to transform the economy through moral principles" [SÉRGIO: 1985: 65]. According to António Sérgio, its preeminent supporter - there were incidentally attempts to show the economic rationality of that system and, consequently, the feasibility of a generalized cooperative system. These efforts were rather inconclusive, and for analytical purposes their authors had to call on neoclassical microeconomics or to make reference to a non existent macro theory [BARROS: 1978]. 
The so called basic needs approach constitued another version of social economics during the 1970's, designing an economic policy in accordance with the values of democratic socialism [RIJCKEGHEM and BARREIROS: 1979]. Its most striking result was a medium-term plan for 19771980 drawn up by the state planning department. Though it was never implemented, it embodied a set of specific goals in relation to the basic needs of the population.

Schumpeterian economics was also incidentally acknowledged, during the 1950's, especially in the context of business cycle discussions [SOUSA: 1950]. However, Schumpeterian views on the theory of economic development and on the entrepreneur were ignored. The scarcity of Portuguese entrepreneurs, the important role of State interventionism, and the survival of models of political authoritarianism to explain the entrepreneur function, help to account for the irrelevance of Schumpeter's ideas.

In respect of structuralism, the situation was somewhat different. The implementation of a pro-growth strategy demanded the analysis of the economic structures to be transformed. This calls for an appropriate set of empirical and theoretic concepts. By 1954, a first result of the efforts to "study the economic structure of the Portuguese mainland (...) just the structure and not a general study on the Portuguese economy" [MOURA, PINTO and NUNES: 1954: 22], was published. New analytical tools such as input-output analysis began then to be used in studies of applied economics [MOURA, PINTO and NUNES: 1954 and TINTNER and MURTEIRA: 1959].

Structuralist economics, influenced by some French and E.C.L.A. economists, namely Raul Prebisch, continued to be discussed during the following two decades. Its main contribution, as an instrument of legitimation of pro-growth attitudes, was to characterize Portuguese backwardness in a very clear and throrough way [PEREIRA: 1954].

However, political constraints compelled the academic versions of structuralism to focus on technical aspects, namely on economic planning techniques. It was purified of some relevant critical views adopted by those Latin-american authors, namely in what concerns the definition of the social basis of the development process and foreign economic policy.

\section{The spread of research and the educational apparatuses}

Just as economic ideas have changed and modernized, the apparatuses specialized in the production and dissemination of those ideas underwent important transformations after the mid 1940 's. One of the outcomes of this process was the advent of the economist profession during the 1960's. 


\subsection{Scientific research apparatuses}

The first research units to be created had a direct relationship with the mentioned above attempt to think out an an original Portuguese corporative economics.

The Centro de Estudos Corporativos [Centre of Corporative Studies], at the Law Faculty of the University of Coimbra was founded in 1941 and was active till 1945. So, it appears to typify the first period of efforts to formulate that theory .

The Gabinete de Estudos Corporativos [Corporative Research Centre] created in 1950 in the I.S.C.E.F, is the result of the initiative of the intellectual leaders of the "second corporative take-off", most of them professors of that Institute. As this project failed, in 1961 this Gabinete turned to sociology, becoming the very first research centre in the subject.

On the other hand, that same Institute had a strong tradition in the teaching of pure mathematics, but not of mathematics applied to economics. As noted above, until the 1940's the Portuguese tradition in economics was dominated by institutionalism and by corporative economics, both of which were adverse to mathematical formalism. However, that situation strarted to change in 1938 when the Centro de Estudos de Matemática Aplicada à Economia - C.E.M.A.E. [Research Centre of Mathematics Applied to Economics], also in the I.S.C.E.F. - started its research activity. This centre, in spite of its short existence, had a crucial role in the evolution of economics in Portugal. It gathered some of the most brilliant Portuguese mathematicians, namely Bento $\mathrm{J}$. Caraça, its founder, and through its research programmes during the 1940's mathematical economics and econometrics were introduced.

The first $\mathrm{Ph}$. D. dissertations on economics using extensively quantitative methods were major results ofC.E.M.A.E.'s activity [FREIRE: 1945; COSTA: 1947 and RODRIGUES: 1947]. Preliminary efforts to calculate Portuguese national income were also initiated. Unfortunately, the government expelled Caraça and all his main collaborators from the university and toppled the C.E.M.A.E. in 1946, for political reasons.

Some time after that purge a new research unit, the Centro de Estudos de Estatística Económica [Economic Statistics Studies Centre], was created to replace the C.E.M.A.E.. It was to have an important role in preparing professors of the I.S.C.E.F., in econometrics. Until 1964, when it ended its activity, it had had collaboration from visiting professors, namely Erich Schneider, Gerhard Tintner, Edmond Malinvaud and René Roy.

The Gabinete de Investigação Económica [Economic Research Centre] was active between 1958 and 1969. It was also a reasearch unit of the I.S.C.E.F. essentially devoted to implement studies of economic theory, especially the omodern theory of economic growth. 
Further significant improvements on economics research in the context of university institutions would only come after 1974. By then, the large expansion of the university institutions came along with the spread of specialized research units and of Ph. D. dissertations more and more akin to international standards, as far as both their contents and the use of formal models is concerned.

In 1945, apart from the University, the Centro de Estudos Económicos [Economic Studies Centre] was founded, also by official initiative, in connection with the the central statistical office. It was supposed to produce economic studies, namely quantitative research using data produced by that bureau, to iluminate state economic interventionism. However, it never had a full time team of researchers. The main expression of its activity was the publication of a journal called Revista do Centro de Estudos Económicos.

Up to the 1960's political decision making always revealed very little appreciation of the importance of applied economic studies. It was only in this decade that some ministries began to organize their own research departments and units, especially in industrial economics. Then a central planning department was established and be responsible in the 1970's for the production of the first macroeconomic models for the Portuguese economy.

Some other institutions, other than universities and public administration, implemented studies on applied economics within their economic reasearch centres. For example, the Secção de Estudos Económicos [Economic Studies Department], created by the Associação Industrial Portuguesa [Portuguese Industrial Association] in 1947, followed by the Gabinete de Estudos de Economia Aplicada [Applied Economics Studies Center]; and the Centro de Economia e Finanças [Economics and Financial Studies Center] of the Fundação Gulbenkian [Gulbenkian Foundation], which existed between 1965 and 1971, deserve to be mentioned. However, the most important of them all was the Gabinete de Estudos [Studies Center] of the Banco de Portugal [Bank of Portugal], expert on short run analyses, have also been producing important studies on Portuguese economy specially since 1975 .

The small number of Ph. D. dissertations presented at the I.S.C.E.F. - 30 between $1931 \mathrm{e}$ 1980 - many of which were outside of these centres, reflects a modest scientific production, specially in what concerns pure investigation. Until very recently, the small group of professors teaching economics in the Portuguese universities, their involvment in public life and in private business, the small dimension of the centres and of their financial resources, the nonprofessionalization of their members, the small number of grants awarded for economic research (see Appendix - table 1), and the political criteria applied to the selection of teachers and researchers during the Estado Novo period explain that state of affairs. 
Only in the 1980's was the fragmentation of the discipline felt, as well as a relative explosion of the number of doctors in economics. Many of them got their degree in other universities in Portugal and abroad.

The appearance of academic economic journals is another sign of progress in scientific research. Mostly of them were published by the above mentioned research centres. Until 1945 Economia e Finanças, published in I.S.C.E.F. from 1931 to 1973, was the only one available. In 1945 the above mentionredRevista do Centro de Estudos Económicos joined it till 1958. The Revista de Economia came out under the initiative of a group of economists previously gathered in C.E.M.A.E. from 1948 to 1964. In 1952 the Faculty of Law of the University of Coimbra started publishing the Boletim de Ciências Económicas. I.S.C.E.F. also published the Revista do Gabinete de Estudos Corporativos, between 1950 and 1961 and Análise Económica, between 1956 and 1969.

Recently, other scientific journals have been published under a different pattern closer to international standard, both in their contents (use of mathematical models, some papers in English, etc) and arrangements (referees). The most relevant ones are Economia, edited by the Universidade Católica Portuguesa [Portuguese Catholic University] since 1977, Estudos de Economia, published by the I.S.C.E.F. since 1980, and Notas Económicas, published by the Faculdade de Economia of the Universidade de Coimbra [Faculty of Economics of the University of Coimbra] since 1993.

In spite of this progress, the semi-peripheral character of Portuguese culture and the language barrier explain the persistent limited external impact of the economic research carried out in the country. After 1950 the most important papers published in the Revista de Economia, sometimes with abstracts in English and French, were mentioned in international economic bibliographies, namely in Documentation Economique, and some well known economists and economic historians, namely Ragnar Frisch, Celso Furtado and Albert Silbert, published some papers in that review. During the 1950's, the future Nobel prizewinners Jan Tinbergen and John Hicks, among other well known European economists, came to lecture at the I.S.C.E.F and published some of their lectures in Economia e Finanças. However, those facts did not significantly change the degree of isolation.

During the 1990's some positive signs are becoming apparent. Actually, as a recent study using data base Social Scisearch of the Institute for Scientific Information [MATA: forthcoming] shows that a closer integration into the international scientific community is being achieved (see Appendix - Tables 2 and 3).

\subsection{The teaching of economic ideas}


The introduction and diffusion of modern economic theory took place basically in State institutions, namely universities and research centres. In the 19th century it was usually in a Law Faculty, but later, in the 20th century, the teaching of economics spread to all schools of commerce, in accordance with what happened in other countries of Continental Europe. The subject thereby achieved a higher status, and was more fully integrated in the university. So, by 1945 economics was an ancillary subject, an auxiliary discipline to the engineering and juridical components in the curricula of the faculties of engineering at the Universidade do Porto [University of Oporto] and the Universidade Técnica de Lisboa [Technical University of Lisbon]; of law at the universities of Coimbra and Lisbon; and also at the above mentioned I.S.C.E.F at the Universidade Técnica de Lisboa, the only university level school dedicated exclusively to economic sciences.

Actually, there, students were supposed to master mathematics, economic geography, economic history, international policy, law, accounting, chemistry and commercial techniques. In its curricula only one discipline dealt specifically with economic theory. A genuine course on economics was not started until the reform of 1949, a decisive contribution to the progress of economic knowledge. Many subjects on commercial techniques and technology were ommited, while many others were introduced into new disciplines. Economic theory was a major subject in four disciplines; the study of financial sciences spread into three syllabus; the traditional course in economic history began to include the history of economic doctrines; new specialized areas, such as the economics of transportation and the economics of the firm, were introduced. Mathematics and statistics teaching was further strenghtened and econometrics was one of the disciplines in the curriculum, while in the teaching of economic theory (from the beginning of the 1950's based on the the neoclassical-keynesian synthesis) mathematical formulation became increasingly apparent. At the same time the teaching of economics and correlative areas came under the responsibility of economists rather than jurists, as it had previously been. Some teaching texts published during the 1950's and the 1960's, on microeconomics [BARBOSA:1950], on macroeconomics [PINTO: 1952], on growth theory [NUNES:1964/65], and on econometrics [MURTEIRA: 1957] illustrate that new state of affairs.

In the following years these curricula and teaching methods were modified in several reforms, for example in 1972, when new disciplines of quantitative methods (e.g. operational research and computing) and new basic economic courses (e.g. international economics and national accounting techniques) were introduced.

During these years new faculties of economics were created, most of them adopting the curricula of the I.S.C.E.F.. The creation of economic faculties in state universities in Oporto in 1953, in Coimbra in 1972, in Lisbon, at the Universidade Nova de Lisboa [New University of Lisbon] in 1977, in Évora in 1981 and in Braga in 1995, were the main examples of this process. The 
I.S.C.E.F. and the Universidade Nova de Lisboa were the first to introduce postgraduate courses in economics in 1981.

There is no strong tradition of private high schools and universities in Portugal but, during the 1980 's, several degrees in economics were created in these institutions. However, scientific research in those private schools has been almost non-existent, and the quality of the teaching is inferior to that in the state faculties. The academic degree at the Universidade Católica Portuguesa, created in 1972, is the only exception.

As far as the scientific curricula are concerned there are some relevant differences among the existing academic degrees.

Some, following the example of I.S.C.E.F., have a tradition of eclecticism and openess to different cultural and theoretical areas, in spite of the teaching being supported by the neoclassicalkeynesian synthesis. It is worth noticing that the reform of 1949 was justified by A. Pinto Barbosa, its main author, as the result of the acknowledgement of the works of Keynes, of the journal Econometrica, of the works of the Institut de Science Economique Appliquée - I.S.E.A. [Institute of Applied Economics] in Paris under the direction of F. Perroux, and the Theory of Games by J. von Neuman and O. Morgenstern [BARBOSA: 1984: 159-160].

In 1957, important but diversified international scientific journals were regularly received at the I.S.C.E.F.. The American Economic Review, Econometrica, Economic Journal, Oxford Economic Papers, Economie Appliquée, Revue d'Economie Politique, Rivista Internazionale di Scienze Sociale and El Trimestre Economico were problaly the most well known out of the twenty eight titles available. I.S.C.E.F.'s library and the research unit of the Banco de Portugal were receiving the important books, including the main textbooks, published in the well-known producing centres of economic ideas.

However, professors of that Institute continued the tradition of producing their own teaching texts and textbooks. Usually, bibliographical references in those textbooks showed much eclectism and included references to paradigms other than the dominant one. Significantly, Economics by P. Samuelson, the reference that was certainly a major instrument in the uniformization of the teaching of economics in the Western world, was never recommended to students as the fundamental textbook before the 1980's.

Other mechanisms of internationalization of economic teaching have been also commonly used, however, again, only significantly in the 1980's. The coming of foreign visiting professors, the sending of assistant teachers to prepare their Ph. D. dissertations at foreign universities have been the most important of those mechanisms. Untill recently, this type of linkage was basically with France and England. In the last decade it has became more geographically diffused, with other European countries (as a result of Portugal's full integration in the EEC since 1986) and the USA rising in importance. 
So, I.S.C.E.F. and most of the other faculties of economics in Portugal have for several decades conformed to the "acceptance of heterodoxy" stated by W. Baumol as being a basic feature of the teaching of economics in Europe [BAUMOL: 1995]. However, the faculties of economics of the Universidade Nova de Lisboa and, in a lesser extent, of the Universidade Católica Portuguesa, adopted $a b$ initio the American pattern. Many visiting professors have come from universities in the U.S.A. and an important percentage of their own professors have got their Ph. D. degree in those universities. Most of bibliographic references in research texts and textbooks are North American mainstream economic literature. Theoretical heterodoxy has been given little attention. During the 1980's, Robert J. Barro's Macroeconomics became the fundamental textbook used in the teaching of macroeconomics. This demonstrates the influence of the North American theoretical fashion, namely in rational expectations theory and monetarist views.

\subsection{The making of the economist profession}

The emergence and increasing recognition of economists as a social and professional group was an important consequence of the process described here both in the research and the teaching of economics.

However, before 1945, as well as during the two following decades, the productivity of the educational system remained very low. The absolute and relative number of students graduating in economics was quite small and, surprisingly, decreasing during the 1950's. Their number only rose significantly after 1969. By 1981, the last year for which information is available, there were 470 new graduates, a total approximately 18 times greater than in 1955 (see Appendix - Table 4).

The small scale of the educational and research systems meant that a limited number of economists was involved. As mentioned before, research activities were basically performed by the few professors of the universities. Untill 1974 there were hardly any professional researchers. At the same time, secondary schools had no economic themes in their curricula, with the sole exception of commercial schools, where the teaching of economics was elementary. However, the scene has changed since then, as economists have been hired to teach at grammar schools as specific economic curricula were introduced.

Even so, the small number of economists during these decades did not prevent them from gaining increasing social visibility in Portuguese society. In 1955, for the first time, an economist graduating from I.S.C.E.F. joined a cabinet of the Estado Novo as Minister of Finance (and some state secretaries and top officials were also economists). Public institutions started to recognize the inevitability of hiring economic experts, and the number of economists working in the public administration rose significantly in the 1960's concurrently with the widening dimensions and 
increasing complexity of the Portuguese public sector. Since then, it has become common to look for expert advisers in matters of economy and finance (e.g. the Commission on Fiscal Reform at the end of the 1950's). The strengthening of Portugal's integration into the world economy, namely when she became a member of several international economic institutions (OEEC in 1948, EPU in 1950, EFTA in 1959, IMF and World Bank in 1961, GATT in 1962) and the need to use a technical, specialized language to participate in their activities reinforced that trend.

Economists began to be in heavy demand in the 1960's. In the private sector, namely in banks and in industrial firms integrated in trusts set up after the World War II. The Companhia União Fabril, the head of a trust installed in banking and in the chemical branch, had a leading role in the practice of hiring economists along with the traditional technical staff of engineers, jurists and accountants. However, a study produced in the mid 1960's showed that only $6 \%$ of the industrialists heading the largest manufacturing enterprises had a degree on economics [Makler: 1969: 143]. By 1989, the last year for which information is available, that percentage had risen to 9\% [SILVA: 1989: 37].

Before the war, the "commercialists" - the traditional name for economist - were represented by a not very influencial trade union at national level. During the war and in the disturbed postwar years, the economists demonstrated some social dynamism, as a group. Scientific associations (e.g. the short living Sociedade de Ciências Económicas [Economic Science Society]) or even of political intervention (e.g. Comissão de Economistas do Movimento de Unidade Democrática [Economist Commitee of the United Democratic Movement] were created, in 1941 and 1949 respectively. By then, the professional trade union became more active, setting up training courses and publishing a bulletin. The efforts to promote their profession went further, once that union fought to become a "professional order", like the other traditional intellectual professions, such as lawyers, and physicians. The government would never allow it, arguing that most economists were wage earners and so lacked the social status of those professions.

The Associação Portuguesa de Economistas - APEC [Portuguese Economists Association] was one, among other professional organizations, to emerge later in 1976. In the begining of the 1990's it had more than 3500 members. Their national meetings have become increasingly publicized.

The increase in the number of specialized publications, and the appearance, in 1954, in the daily newspapers, namely in the Diário de Lisboa, of specific pages devoted to economic affairs were also important contributions to the economists' identification as a professional group in the post-war years.

A similar importance may certainly be attributed to the organization of the fcongresses of economists, which gathered together a significant number of academic and non academic professionals. The first took place in Angola in 1955; the second, the most important one, took 
place in Lisbon in 1957. Debates focused basically on economic policy; presentations of results of economic research were rare. Especially after 1957 it was clear that economists, and no longer engineers, were the authors of the most sophisticated developmental strategies, inverting the traditional trends of the early decades of the 2century.

Since the 1980's the presence of economists has increased further. A specialized press on economic matters has emerged as well as a large quantity of economic information on newspapers and on TV stations. This has helped to raise the demand for economists and their public reputation as a professional group.

The increasing dependence of politics upon economic discourse has strenghtened the social influence of economists. The growing involvment of economists - mainly professors - in public affairs to legitimise the conflicting strategic views in the Portuguese society is internal to the present working of the political system.

\section{Concluding remarks}

In the previous sections it became clear that Portugal experienced, after 1945, a process of modernization of economics parallel to the process of modern economic growth. However that process accelerated in consequence of the process of internationalization of the economy, first in the 1960's but, above all, in the 1980's.

As far as economic theory and doctrines are concerned, modernization meant the minimizing of indigenous original approaches (mainly corporative economics), and the adoption of the same patterns of economic discourse as existed abroad. The import of these patterns was never homogeneous. Ideas were introduced and diffused after some transformation according to the cultural and strategic particularities of Portuguese society during the last half century.

The educational apparatus was conditioned by political and social conceptions of a voluntarist, elitist character. The late expansion of the faculties of economics, the small number of graduates, and the absence of the teaching of economics at the intermediate level of education, are an apparent outcome of those conditionings, not to mention the only recent introduction of postgraduate education and the spread of the $\mathrm{Ph}$. D. in economics.

The research apparatus underwent three phases of evolution. Till 1945 it was either absent or short lived; during the next three and a half decades, there was a slow expansion of those organizations; since the 1980's they have grown in number, their international contacts have become more regular. As a result, only in this period has a true scientific community been installed, thanks also to the cultural and political freedom brought about in 1974, when the crude sectarian system of co-optation of professors was dismantled. 
Formal and informal networks of Portuguese researchers have been created only very recently. However, the level of mutual citation among them remains very low, and most of their work is still ignored by the international scientific community. The habit of producing their scientific results in the English language is a still more recent development.

In association with the spread of modern economics the economists, as a social group, have emerged since the 1960's. Two main reasons may account for this:

i. modern economic growth, which raised the demand for their expertise both in the public as well as in the private sector, again, apparent after 1960.

ii. a self-conscious development of an active strategy of self-promotion.

Modernization and the internationalization of economics, as well as the social self-imposing of economists, was slow, late, in many aspects. This was inevitable as modern economic growth dates only from the 1950's and the relatively successful process of catching-up did not prevent Portugal from remaining a semi-peripherical economy and society. In spite of that, there was a parallel process of a sucessful convergence in economics, with no diverging periods. 


\section{References}

ABREU, L. Simões de: 1948, Algumas notas sobre as teorias de Keynes, in Revista de Economia, $\mathrm{n}^{\circ}$ $1(3)$.

ABREU, L. Simões de: 1949, Política fiscal e Keynesianismo, in Revista de Economia, nº 2(1).

ALARCÃO, Jorge: 1948, Estimativa do nível de vida da população operária portuguesa, in Revista de Economia, $n^{\circ} 1(1)$.

BARBOSA, A. M. Pinto: 1943, A economia do ponto de vista positivo e do ponto de vista teleológico, in Economia e Finanças, vol.11.

BARBOSA, A. M. Pinto: 1950(1 and 2), Economia I, 2 vol., Lisboa (mimeog.).

BARBOSA, A. M. Pinto: 1984, A reabilitação do quantitativo na Economia, in Boletim de Ciências Económicas, $\mathrm{n}^{\circ} 27$.

BARROS, Henrique de: 1978, A doutrina cooperativa e as ciências sociais, in Estudos em homenagem ao Prof. Doutor J. J. Texeira Ribeiro, Coimbra.

BASTIEN, Carlos: 1989, Para a história das ideias económicas no Portugal contemporâneo: a crise dos anos 1945-1954 [Ph. D. dissertation], Lisboa, ISEG/UTL (mimeog.).

BASTIEN, Carlos: 1993, Marxism, labour movement and culture in Portugal, in Estudos de Economia, vol. 13(2).

BAUMOL, William J.: 1995, What's Different about European Economics ?, in Kyklos, vol. 48.

BELEZA, J. Pizarro: 1955, Teoria do Juro - a controvérsia keynesiana, Coimbra.

CASTRO, Armando: 1945, Alguns aspectos da agricultura nacional, Coimbra.

CASTRO, Armando: 1948, Origem e destino da teoria subjectiva do valor, in Revista de Economia, $\mathrm{n}$ ${ }^{\circ} 1(3)$.

CASTRO, Armando: 1949, A indústria nacional e a expansão do mercado interno, in Indústria Portuguesa, $\mathrm{n}^{\circ} 252$.

CASTRO, Armando: 1983, Lições de Economia, Lisboa.

CARDOSO, J. Pires: 1949, Uma escola corporativa portuguesa, Lisboa.

CORREIA, J. D. Araújo: 1952, Elementos de planificação económica, Lisboa.

COSTA, A. M. Sá da: 1947, Sobre alguns problemas da teoria das cadeias de mercado, Lisboa.

CUNHAL, Álvaro: 1964, Rumo à Vitória, (not indicated).

CUNHAL, Álvaro: 1966, A questão agrária em Portugal, Rio de Janeiro.

DIAS, J. Ferreira: 1945, Linha de rumo, Lisboa. 
FREIRE, J. Remy: 1945, Estudos de demografia portuguesa, Lisboa.

GUEDES, A. Marques: 1944-1946, Notas para um curso de Economia Política, in Economia e Finanças, vol. 12-14.

LEAL, A. Costa and FALCÃO, J. M. Silva: 1952, Sobre a observação estatístca das finanças públicas, in Revista de Economia, $n^{\circ}$ 5(4).

LEITE, João Pinto da Costa: 1933, Ensaio sobre a teoria das crises económicas, Coimbra.

MAKLER, Harry M.: 1969, A "elite" industrial portuguesa, Lisboa.

MARQUES, Hernani: 1934, Economia Política, Coimbra.

MARTINEZ, P. Soares: 1960, Sentido económico do corporativismo, Lisboa.

MARTINS, Rogério: 1970, Caminho de país novo, Lisboa.

MATA, José (forthcoming], A investigação em economia em Portugal: 1980-1994, Lisboa.

MOURA, F. Pereira de: 1964, Lições de Economia, Lisboa.

MOURA, F. Pereira de: 1969a, Análise económica da conjuntura, Lisboa.

MOURA, F. Pereira de: 1969b, Por onde vai a Economia Portuguesa ?, Lisboa.

MOURA, F. Pereira de; PINTO, L. M. Teixeira; NUNES, M. Jacinto: 1954, Estrutura da economia portuguesa, in Revista do Centro de Estudos Económicos, $\mathrm{n}^{\circ} 14$.

MOURA, F. Pereira de, PINTO, L. M. Teixeira and NUNES, M. Jacinto: 1954, Estrutura da economia portuguesa, in Revista do Centro de Estudos Económicos, $n^{\circ} 14$.

MURTEIRA, Bento F.: 1957, Econometria. I curso. Apontamentos baseados nas lições do Prof. Bento Murteita, proferidas no ano lectivo de 1955/56, Lisboa (mimeog.).

NETTO, António Lino: 1936, Elementos de Economia Politica, Lisboa.

NUNES, A. Sedas: 1952, Crise social e reforma da empresa, in Revista do Gabinete de Estudos Corporativos, $\mathrm{n}^{\circ} 10$ and 11 .

NUNES, M. Jacinto: 1964/65, Economia III, notas para estudo, Lisboa (mimeog.).

NUNES, M. Jacinto: 1956, Rendimento Nacional e Equilíbrio Orçamental, Lisboa.

NUNES, M. Jacinto: 1986, Algumas notas sobre o keynesianismo em Portugal, in Eduardo Sousa Ferreira e José Luis Cardoso (org.), O cinquentenário da Teoria Geral de Keynes, Lisboa, ISE.

OLIVEIRA, A. Águedo de: 1947, Portugal perante as tendência da economia mundial, Lisboa.

PEREIRA, A. Gonçalves: 1935, As novas exigências da economia política, in Economia e Finanças, $n^{\circ} 3$.

PEREIRA, A. Ramos: 1954, Portugal e o quadro das estruturas económicas subdesenvolvidas, in Revista de Economia, $n^{\circ} 7(1)$. 
PEREIRA, R. da Silva: 1953, Perspectivas da Planificação Economica in Revista do Gabinete de Estudos Corporativos, $n^{\circ} 13$.

PINTO, L. M. Teixeira: 1952, Algumas notas sobre o equilibrio keynesiano, in Economia e Finanças, vol. 20.

PINTO, L. M. Teixeira: 1956, Alguns aspectos da teoria do crescimento, Lisboa.

PIRES, F. Lucas: 1973, O Estado pós-corporativo, in Revista da Corporação dos Transportes e Turismo, $\mathrm{n}^{\circ} 2$

RIJCKEGHEM, Willy van; BARREIROS, Lidia: 1979, Employment and basic needs in Portugal, Geneva.

RODRIGUES, O. Morbey: 1947, O problema dos orçamentos familiares, Lisboa.

SÉRGIO, António: 1947, Alocução aos socialistas, Lisboa.

SÉRGIO, António: 1985, Sobre o sistema cooperativista, Lisboa.

SILVA, Manuela: 1989, Empresários e gestores da indústria em Portugal, vol.1, Lisboa (mimeog.).

SILVA, F. Gonçalves da: 1953, A evolução da empresa - III, in Indústria Portuguesa, nº 306.

SOUSA, Antonino de: 1950, O Keynesianismo e as suas directrizes, in Erich Roll, História do Pensamento Económico, vol. 2, Lisboa.

TINTNER, Gerhard and MURTEIRA, Bento: 1959, Um modelo 'input - output' simplificado para a economia portuguesa, in Economia e Finanças, vol. 27(1).

ULRICH, Ruy Ennes: 1948, Economia Política (circulação), Lisboa.

VEIGA, A. J. Motta: 1944, A economia corporativa e o problema dos preços, Lisboa.

XAVIER, Alberto P.: 1973, Economia de mercado e justiça social, Lisboa. 


\section{Appendix}

Table 1 - Grants for scientific research ${ }^{\text {a) b) }}$ publications

organizations $^{\text {a) }}$

\begin{tabular}{lrc}
\hline year & total & economics \\
& & \\
\hline 1940 & 90 & 0 \\
1941 & 91 & 0 \\
1942 & 100 & 0 \\
1943 & 94 & 0 \\
1944 & 84 & 0 \\
1945 & 102 & 0 \\
1946 & 122 & 0 \\
1947 & 118 & 7 \\
1948 & 122 & 8 \\
1949 & 96 & 8 \\
1950 & 121 & 8 \\
1951 & 116 & 9 \\
1952 & 125 & 10 \\
1953 & 149 & 3 \\
1954 & 138 & 5 \\
& &
\end{tabular}

Source: Anuário Estatístico.

Notes: a) Public sector only.

included in

b) Official statistics do not include data for the period after 1954 .

and other
Table 2 - Economic scientific

by authors in Portuguese

\begin{tabular}{lr} 
year & publications \\
\hline 1980 & 1 \\
1981 & 3 \\
1982 & 1 \\
1983 & 0 \\
1984 & 0 \\
1985 & 0 \\
1986 & 6 \\
1987 & 5 \\
1988 & 4 \\
1989 & 6 \\
1990 & 6 \\
1991 & 5 \\
1992 & 10 \\
1993 & 14 \\
1994 & 12 \\
\end{tabular}

Source: Mata (forthcoming). a) Publications in reviews Social Scisearch only.

b) Papers only. Small notes publications not included. 
Table 3 - Economic scientific publications in Western Europe (1980-1994) ${ }^{\text {a) }}$

\begin{tabular}{lrc}
\hline country & publications & $\begin{array}{c}\text { publications/ } \\
\text { /population }\end{array}$ \\
\hline Austria & 870 & 111.5 \\
Belgium & 1633 & 165 \\
Denmark & 899 & 176.3 \\
Finland & 808 & 161.6 \\
France & 2942 & 51.6 \\
Germany & 1502 & 18.7 \\
Greece & 247 & 24.7 \\
Ireland & 1223 & 349.4 \\
Italy & 2195 & 38.4 \\
Luxemburg & 157 & 392.5 \\
Netherlands & 2373 & 158.2 \\
Norway & 624 & 145.1 \\
Portugal & 89 & 8.4 \\
Spain & 445 & 11.4 \\
Sweden & 1321 & 157.3 \\
Switzerland & 1215 & 189.3 \\
U. Kingdom & 21925 & 382 \\
& & \\
\hline
\end{tabular}

Source: MATA (forthcoming).

Notes: a) publications in reviews included in Social Scisearch only. 
Table 4 - Graduates in higher schools and universities ${ }^{\text {a) }}$

\begin{tabular}{|c|c|c|c|c|c|}
\hline year & total & $\begin{array}{l}\text { economics } \\
\text { and business } \\
\text { administration }\end{array}$ & $\begin{array}{l}\text { economics } \\
\text { and business } \\
\text { administration }\end{array}$ & $\begin{array}{c}\text { "modern } \\
\text { economics" }\end{array}$ & $\begin{array}{l}\text { "modern } \\
\text { economics" }\end{array}$ \\
\hline
\end{tabular}

$(\%)$

\begin{tabular}{|c|c|c|c|c|c|}
\hline 1940 & 1060 & 109 & 10.3 & • & • \\
\hline 1941 & 1123 & 22 & 2 & - & • \\
\hline 1942 & 989 & • & • & • & • \\
\hline 1943 & 1143 & 59 & 5.2 & • & - \\
\hline 1944 & 1219 & 47 & 3.9 & - & • \\
\hline 1945 & 1214 & 62 & 5.1 & • & • \\
\hline 1946 & 1293 & 63 & 4.9 & • & - \\
\hline 1947 & 1281 & 71 & 5.5 & • & - \\
\hline 1948 & 1407 & 53 & 3.8 & • & • \\
\hline 1949 & 1270 & 95 & 7.5 & 0 & 0 \\
\hline 1950 & 1369 & 107 & 7.8 & 0 & 0 \\
\hline 1951 & 1337 & 91 & 6.8 & 0 & 0 \\
\hline 1952 & 1451 & 80 & 5.5 & 0 & 0 \\
\hline 1953 & 1406 & 53 & 3.8 & 0 & 0 \\
\hline 1954 & 1299 & 56 & 4.3 & 4 & .3 \\
\hline 1955 & 1959 & 55 & 2.8 & 26 & 1.3 \\
\hline 1956 & 1975 & 46 & 2.3 & - & - \\
\hline 1957 & 2095 & 43 & 2.1 & 23 & 1.1 \\
\hline 1958 & 2237 & 65 & 2.9 & - & - \\
\hline 1959 & 2199 & 64 & 2.9 & 32 & 1.5 \\
\hline 1960 & 2263 & 75 & 3.3 & - & - \\
\hline 1961 & 2063 & 67 & 3.2 & 36 & 1.7 \\
\hline 1962 & 1994 & 73 & 3.7 & - & - \\
\hline 1963 & 2278 & 77 & 3.4 & 58 & 2.5 \\
\hline 1964 & 2164 & 72 & 3.3 & - & - \\
\hline 1965 & 2704 & 100 & 3.7 & 77 & 2.8 \\
\hline 1966 & 2542 & 120 & 4.7 & - & - \\
\hline 1967 & 2959 & 101 & 3.4 & 73 & 2.5 \\
\hline 1968 & 2782 & 150 & 5.4 & - & - \\
\hline 1969 & 2406 & 156 & 6.5 & 114 & 4.7 \\
\hline 1970 & 3321 & 202 & 6.1 & 135 & 4.1 \\
\hline 1971 & 3068 & 227 & 7.4 & 166 & 5.4 \\
\hline 1972 & 3082 & 271 & 8.8 & 159 & 5.2 \\
\hline 1973 & 3613 & 512 & 14.2 & 244 & 6.8 \\
\hline 1974 & 6414 & 569 & 8.9 & 261 & 4.1 \\
\hline 1975 & 4339 & 1007 & 23.2 & 388 & 8.9 \\
\hline 1976 & 9676 & 1255 & 13 & 635 & 6.6 \\
\hline 1977 & 9723 & 759 & 7.8 & 418 & 4.3 \\
\hline 1978 & 12624 & 1042 & 8.3 & 554 & 4.4 \\
\hline 1979 & 10551 & 480 & 4.5 & 224 & 2.1 \\
\hline 1980 & 10101 & 997 & 9.9 & 415 & 4.1 \\
\hline 1981 & 10942 & 1162 & 10.6 & 470 & 4.2 \\
\hline
\end{tabular}

Source: Anuário Estatístico and Estatística da Educação. Notes:

a) Official statistics do not include specific data for the period after 1981 .

b) "Modern economics" refers to graduates in economics after the curricula introduced in 1949 . 